\title{
ANALISIS PERANAN KADER POSYANDU TERHADAP MANAJEMEN PENANGANAN BALITA KEP DI PUSKESMAS RAJA BASA INDAH BANDAR LAMPUNG TAHUN 2017
}

\author{
Festy Ladyani1, Dwi Ruth Rahayuning Asih Budi2
}

1Departemen Ilmu Gizi Medik, Fakultas Kedokteran, Universitas Malahayati 2Program Studi Kedokteran, Fakultas Kedokteran, Universitas Malahayati

\begin{abstract}
Analysis of the Role of Posyandu Cadres on Handling Management of Toddler KEP in Raja Basa Indah Health Center in Bandar Lampung in 2017. Malnutrition is the highest level condition from lack of nutrition that happens in children and is caused by a chronic lack of nutrition intake. Status monitoring results of malnutrition in Lampung province in 2016 are found for 251 cases. Based on data of of Raja Basa Indah health center Bandar Lampung in 2016 there were 16 infants BGM and were undergoing treatment. Posyandu (center for pre-and post natal health care and information for woman and infant) volunteer has important work as a health provider who discovers and handles malnutrition cases for the first time, because it was near to Posyandu activity target and because the volunteer/helper meet and work with them more often than any other health care workers on the community. To analysis the management of handling health posts against malnutrition children in 2017. Kind of research is descriptive research with a qualitative approach. Informant selection techniques done by non-probability purposive sampling. Data was collected by means of structured interview and indepth interviews. Analysis of the data by using triangulation with the coordination of nutrition, health posts, and neighbourhood head. The total numbers of informants are three people. It was obtained the role of Posyandu agents on toddlers management has been going well.
\end{abstract}

Keywords: Role, Management, Energy Malnutrition Protein (EMP), Health Posts

\begin{abstract}
Abstrak: Analisis Peranan Kader Posyandu Terhadap Manajemen Penanganan Balita KEP di Puskesmas Raja Basa Indah Bandar Lampung Tahun 2017. Gizi buruk merupakan keadaan kurang gizi tingkat berat pada anak yang disebabkan kurangnya asupan gizi yang berlangsung lama (kronis). Hasil Pemantauan Status Gizi (PSG) tahun 2016 di Provinsi Lampung tentang kasus gizi buruk pada tahun 2016 sebanyak 251 kasus. Berdasarkan data Puskesmas Raja Basa Indah Bandar Lampung tahun 2016 terdapat 16 balita BGM dan sedang menjalani penanganan. Kader posyandu mempunyai peran yang penting karena merupakan pelayan kesehatan (health provider) yang pertama kali menemukan kasus gizi buruk serta menangani kasus itu dikarenakan berada di dekat kegiatan sasaran Posyandu dan kader memiliki frekuensi tatap muka lebih sering daripada petugas kesehatan lainnya di masyarakat. Untuk menganalisis peranan kader posyandu dalam manajemen penanganan balita Kurang Energi Protein (KEP) tahun 2017. Rancangan penelitian menggunakan desain penelitian deskriptif dengan pendekatan kualitatif. Teknik pemilihan informan dilakukan dengan cara teknik non-probability purposive sampling. Pengambilan data dengan cara wawancara terstruktur dan mendalam. Analisis data dengan cara triangulasi dengan informan koordinator gizi, kader posyandu, ketua RT. Jumlah keseluruhan informan sebanyak 3 orang. Didapatkan peran kader posyandu dalam manajemen penanganan terhadap balita KEP sudah berjalan dengan baik.
\end{abstract}

Kata Kunci: Peranan, Manajemen, KEP, Kader Posyandu 


\section{PENDAHULUAN}

Gizi merupakan zat yang diperlukan oleh tubuh untuk melakukan fungsinya, yakni menghasilkan energi, membangun dan memelihara jaringan, serta mengatur proses- proses kehidupan, status gizi masyarakat dapat diketahui dan dinilai melalui penilaian, yaitu: antropometri, klinis, biokimia, biofisik. (Supariasa, 2001).

Berdasarkan Riskesdas 2013, Indonesia mengalami peningkatan angka anak yang mengalami underweight yaitu 18,3\% (2007); $17,9 \%$ (2010); dan 19,6\% (2013). Untuk kategori Stunting (TB/U), Indonesia pada tahun 2013 mengalami peningkatan dari tahun $2010(33,65)$ menjadi $37,2 \%$ di tahun 2013. Dan terjadi penurunan persentase pada anak yang mengalami wasting (BB/TB) dari tahun 2007 sebesar 13,6\% dan 2010 sebesar $13,3 \%$ menjadi $12,1 \%$ pada tahun 2013. Hasil Pemantauan Status Gizi (PSG) tahun 2016 di Provinsi Lampung tentang kasus gizi buruk pada tahun 2016 sebanyak 251 kasus. (Dinkes, 2016).

Posyandu merupakan salah satu bentuk pendekatan partisipasi masyarakat di bidang kesehatan yang dikelola oleh kader posyandu yang telah mendapatkan pendidikan dan pelatihan dari Puskesmas. Kader posyandu mempunyai peran yang penting karena merupakan pelayan kesehatan (health provider) yang berada di dekat kegiatan sasaran posyandu serta frekuensi tatap muka kader lebih sering daripada petugas kesehatan lainnya. Kader memantau perkembangan balita, apabila ditemukan gangguan perkembangan, diberikan cara-cara untuk merangsang perkembangan anak, selain itu dia melaporkan gangguan perkembangan anak kepada petugas kesehatan untuk diteruskan kepada dokter Puskesmas. (Ina Hernawati, 2009). Dampak kurang dilaksanakan peran kader posyandu akan memberikan akibat baik secara langsung maupun tidak langsung.
Dampak secara langsung bagi anak, pemantauan tumbuh kembang yang kurang baik menyebabkan tidak termonitornya kesehatan anak. Dampak tidak langsung penerapan di Posyandu juga kurang tepat. (Fitri W, 2005)

\section{METODE}

$\begin{array}{lr}\text { Rancangan } & \text { penelitian } \\ \text { menggunakan desain } & \text { penelitian } \\ \text { deskriptif dengan pendekatan }\end{array}$ kualitatif. Teknik pemilihan informan dilakukan dengan cara teknik nonprobability purposive sampling. Pengambilan data dengan cara wawancara terstruktur dan mendalam. Analisis data dengan cara triangulasi dengan informan koordinator gizi, kader posyandu, ketua RT. Jumlah keseluruhan informan sebanyak 3 orang

HASIL

Hasil Penelitian Kualitatif

Fokus I Gambaran Tentang

Perencanaan Dalam Manajemen

Penanganan Balita KEP

\section{Informan 1}

Kunci Petugas Gizi (PG)

"Mekanisme mengenai informasi masalah gizi di wilayah kerja Puskesmas Raja Basa Indah biasanya didapatkan dari kader posyandu setiap kegiatan posyandu dilakukan melalui pengukuran berat badan dan melihat tanda-tanda klinis serta melakukan kunjungan rumah bagi orangtua yang memiliki bayi tetapi tidak pernah datang pada saat dilaksanakan posyandu. Pada kasus balita KEP ini petugas Gizi mengetahuinya dari Dinas Kesehatan Kota Bandar Lampung dan Puskesmas Kedaton Bandar Lampung yang memberitahu bahwa ada satu anak yang memiliki berat badan yang tidak sesuai dengan umur dan tinggi badannya di wilayah kerja Puskesmas Raja Basa Indah Bandar Lampung. Ketika mengetahui hal tersebut Petugas Gizi Puskesmas langsung memberitahu para kader dan bidan 
desa di wilayah tempat tinggal anak tersebut untuk mengecek apakah benar orangtua dan anak tersebut tinggal di alamat tersebut dan langsung melakukan perencanaan penanganan pada Balita KEP dengan membentuk tim penyusun rencana program PMT dengan melibatkan bidan desa dan kader kesehatan. Kami melakukan pertemuan dahulu sebelum mengunjungi rumah balita tersebut, untuk mendiskusikan masalah ini kenapa bisa terjadi, kegiatan-kegiatan diposyandu dan kenapa balita KEP ini tidak diketahui dan diketahui dari Puskesmas lain dan Dinas Kesehatan Kota Bandar Lampung. Setelah mendapatkan informasi dari para kader dan bidan desa bahwa benar anak tersebut tinggal di wilayah kerja puskesmas Raja Basa Indah petugas gizi Puskesmas dan petugas kesehatan lainnya langsung mendatangi rumah balita tersebut. Didalam perencanaan penanganan Petugas Gizi tidak mempunyai hambatan dalam melakukan perencanaan seperti menggerakkan para bidan desa dan kader kesehatan dalam mengecek alamat balita KEP dan perencanaan pelaksanaan program PMT serta mendatangi keluarga balita untuk memberikan konseling bersama para kader, bidan desa dan petugas kesehatan lainnya. Ketika dilakukan tanya jawab didapatkan informasi bahwa orangtua dan balita KEP dulunya tinggal di wilayah kerja puskesmas Kedaton Bandar Lampung dan baru saja pindah rumah ke wilayah puskesmas Raja Basa Indah dikarenakan ibu balita akan melahirkan anak ketiga akan tetapi kartu BPJS orangtua balita berada di wilayah puskesmas Raja Basa Indah maka dari itu Dinas Kesehatan Kota Bandar Lampung dan puskesmas Kedaton Bandar Lampung memberitahu kepada petugas gizi Puskesmas Raja Basa Indah bahwa ada anak di wilayah kerja Puskesmas Raja Basa Indah yang mengalami gizi buruk dengan penyakit penyerta TB."

\section{Informan 2 \\ Kader Posyandu (KP)}

"Untuk proses penemuan kasus balita KEP ini didapat dari pihak puskesmas yang memberitahu kami para kader dan bidan desa bahwa ada salah satu anak di wilayah posyandu kami yang berat badannya tidak sesuai dengan berat badan normal anak seumurannya. Ketika mengetahui hal tersebut, kami para kader, dan bidan desa langsung mendatangi rumah balita KEP tersebut untuk memastikan dengan membawa alat antropometri seperti menimbang berat badan, mengukur tinggi badan, mengukur lingkar kepala dan memeriksa kemampuan motorik kasar dan kemampuan motorik halus balita tersebut. Balita tersebut di periksa nafsu makannya dengan cara menanyakan kepada orangtua apakah anak mau makan/tidak mau makan minimal dalam tiga hari berturut-turut untuk mengetahui apakah anak tersebut tampak sangat kurus apabila nafsu makannya baik makan anak tersebut dikategorikan gizi buruk tanpa komplikasi dan perlu diberikan penanganan secara rawat jalan. Dan ketika dilakukan tanya jawab kepada orang tua balita didapatkan informasi bahwa balita tersebut pernah diperiksa di RS Advent Bandar Lampung dan diberitahu bahwa terdapat flek di paru- paru si anak dan benjolan dibelakang kuping si anak. Ketika mengetahui hal tersebut bidan desa dan kader langsung memeriksa balita secara keseluruhan dengan meminta orangtua untuk melepaskan pakaian si anak dan melaporkan hal ini ke pelayanan gizi Puskesmas untuk dilakukan validasi lebih lanjut serta mengukur kembali $B B$ dengan menggunakan indeks BB/TB. Setelah didapatkan hasil tentang status gizi balita tersebut dan dipastikan bahwa balita tersebut mengalami gizi buruk maka akan dimasukkan dalam daftar penderita gizi buruk yang akan mendapatkan penanganan lebih lanjut." 
Informan 3 Ketua RT (KRT) :

"Dalam kasus gizi buruk di wilayah ini pertama kali yang menemukan adalah petugas gizi dari Puskesmas Raja Basa Indah dan kader posyandu. Setelah itu kader melapor kepada saya bahwa ada salah satu anak di wilayah saya yang mengalami gizi buruk. Sebelumnya tidak pernah ditemukan adanya kasus gizi buruk di lingkungan ini, dan saya langsung mengunjungi rumah warga tersebut. Ketika saya mendatangi rumah tersebut, saya baru mengetahui bahwa adanya satu keluarga tersebut yang tinggal di wilayah ini dan ternyata keluarga tersebut baru saja pindah beberapa bulan yang lalu ke wilayah ini dan belum melapor kepindahannya ke wilayah ini. Dari pihak posyandu dan Puskesmas selalu melakukan koordinasi dengan saya dalam melaksanakan kegiatan posyandu seperti jadwal posyandu, penjaringan dan pelacakan gizi buruk/BGM atau $2 T$ serta dalam penanganan balita KEP untuk mendongkrak balita gizi buruk supaya meningkat status gizinya dalam pemberian PMT serta penyuluhan tentang gizi kepada orang tua balita tersebut. Dan ketika ditemukan bahwa ada salah satu anak yang mengalami KEP di wilayah ini saya ikut turut serta bekerja sama dengan para kader posyandu dan petugas gizi Puskesmas Raja Basa Indah dalam perencanaan penanganan balita KEP ini, seperti mencari solusi dan ikut melakukan kunjungan ke rumah balita KEP tersebut agar dicari tahu apa penyebabnya dan langkah yang harus ditempuh untuk menaikkan status gizi serta berat badannya."

\section{Fokus II Gambaran Tentang Pelaksanaan Dalam Manajemen Penanganan Balita KEP}

\section{Informan Kunci Petugas Gizi (PG)} "Sebagai pengelola gizi dalam menangani kasus balita KEP yaitu biasanya kami melakukan kunjungan pada pasien ini bersama petugas kesehatan lainnya dan para kader posyandu sebanyak sepuluh hari dalam sebulan, sehingga bisa sampai 3-4 kali dalam sebulan melakukan kunjungan tersebut. Untuk mengatasi masalah ini maka diselenggarakan Pemberian Makanan Tambahan (PMT) Pemulihan. PMT Pemulihan dimaksudkan untuk memenuhi kebutuhan gizi balita, sekaligus sebagai proses pembelajaran dan sarana komunikasi dengan ibu balita. Dari pihak Puskesmas akan memberikan PMT maupun MP-ASI kepada kader dan kemudian kader akan memberikannya sebanyak dua puluh kotak PMT kepada balita, dan ditargetkan harus habis dua kotak setiap minggu selama tiga bulan. Pada kasus ini yang menjadi penanggung jawab adalah saya selaku koordinator pengelola gizi. Target yang ingin dicapai terhadap balita KEP ini yaitu kenaikan BB. terutama melalui pengukuran antropometrinya jika BB sudah mencukupi/ mencapai standar. Pada kasus yang sedang ditangani ini kirakira sudah 10 kali kunjungan dari awal penemuan, di rujuk kerumah sakit, hingga sampai hari ini. Kami juga memberikan konseling kepada orangtua pasien, untuk menyepakati tindakan untuk meningkatkan pertumbuhan anak yang dapat dilaksanakan oleh ibu atau pengasuh dimana kegiatan konseling ini dilakukan secara tatap muka kepada orang tua anak. Pemberian konseling ini perlu dilakukan untuk menyampaikan informasi kepada orangtua tentang hasil penilaian pertumbuhan anak dan untuk memberikan anjuran pemberian makanan sesuai umur dan kondisi anak dan cara menyiapkan makanan, melaksanakan anjuran makan dan memilih atau mengganti makanan. Pada kasus ini harus dianjurkan makan dengan makanan yang lengkap, makanan lengkap adalah makanan yang harus mengandung karbohidrat, sumber protein, ada sumber vitamin dan sebagainya. Untuk frekuensinya adalah sesering mungkin. Pada kasus ini memang 
anak susah sekali makan, dia tidak mau makan ayam, telur, sayur dan sebagainya sehingga cara menyiasatinya adalah menganjurkan ibunya agar mengolah bentuk makanan agar tidak seperti bentuk makanan. Sebagai contoh misalnya selipkan sayur didalam makanan si anak. Dalam kasus ini belum terlihat perkembangan tetapi kami masih mengusahakannya. Dalam kasus ini Ibu pasien mempunyai riwayat KEK pada masa kehamilannya dan belum pernah datang berobat ke puskesmas dan setelah mengetahui bahwa anaknya terkena kurang Gizi"

\section{Informan 2 Kader Posyandu (KP)}

"Ketika ditemukan bahwa ada balita dengan berat badan tidak naik 3 kali ("3T"), kader memberikan PMT Pemulihan yang dimaksudkan untuk memenuhi kebutuhan gizi balita, sekaligus sebagai proses pembelajaran dan sarana komunikasi antar ibu dari balita sasaran dan diberikan penyuluhan gizi seimbang. Makanan tambahan diberikan sekali sehari selama 90 hari berturut-turut, berbasis makanan lokal yang terdiri dari 2 (dua) jenis, yaitu berupa Makanan Pendamping Air Susu Ibu (MP-ASI), untuk bayi dan anak berusia 6-23 bulan dan makanan tambahan untuk pemulihan anak balita usia 2459 bulan berupa makanan keluarga lainnya. Kader menganjurkan makanan beraneka ragam untuk anggota keluarga. Kader menimbang berat badan anak setiap 2minggu sekali untuk memantau perubahan berat badan dan mencatat keadaan kesehatannya. Surveilans gizi dilakukan setiap minggu oleh kader kesehatan dengan mengunjungi rumah balita gizi buruk serta mengadakan pengamatan secara terus-menerus terhadap tumbuh kembang balita gizi buruk dan kurang yang merupakan kelompok binaannya masing-masing. Kegiatan surveilans gizi difokuskan pada pengukuran antropometri (Berat Badan, Panjang Badan/Tinggi Badan, Lingkar Lengan Atas (LILA), pemantauan porsi PMT
Pemulihan (Pan-Enteral) yang dikonsumsi balita, serta berbagai bentuk keluhan/penyakit penyerta yang dialami balita. Hasil pemantauan kader dicatat dalam buku harian kader dan kartu Tumbuh Kembang Balita yang ada di rumah masing-masing balita. Banyak kendala selama kegiatan ini berlangsung, terutama dari ibu balita dan balita itu sendiri. Pada awal kegiatan intervensi dilakukan, kader dan tenaga pendamping kesulitan untuk memberi pembelajaran kepada ibu balita. Umumnya ibu balita tidak menerima kalau anaknya dikatakan gizi buruk, karena dalam persepsi mereka anak gizi buruk adalah anak yang kurus kering dan tidak dapat beraktivitas secara normal (dalam hal ini anak gizi buruk yang dimaksud adalah anak yang sudah menderita gizi buruk kronik yang biasa dikenal sebagai marasmus, kwarsiorkor atau marasmic- kwarsiorkor). Rendahnya tingkat pengetahuan ibu (80\%) memberi kendala dalam hal penerimaan pengetahuan dan keterampilan yang diberikan. Solusi dalam mengatasi hal ini dilakukan dengan memberitahukan dampak gizi buruk yang terjadi jika anak tidak diintervensi dan pemberian motivasi kepada ibu balita berupa motivasi pengasuhan yang mengangkat dan mendorong antusiasme ibu sehingga dapat menerima program ini dengan baik.

Kesulitan menilai apakah terjadi kenaikan BB balita PMT adalah balita tidak datang pada saat posyandu dan ditemukan adanya paket PMT setelah sampai dirumah tidak seluruhnya sampai di mulut sasaran tetapi juga diberikan kepada kakak atau adiknya yang masih tergolong balita namun bukan termasuk sasaran dan ketika dilakukan kunjungan ke rumah keluarga balita gizi buruk sedang pergi. Demikian juga dengan kesadaran orangtua balita akan pentingnya makanan bergizi bagi pertumbuhan anak masih rendah sehingga balita masih diberi makan "sekedarnya" atau asal kenyang 
padahal rendah kandungan gizi. Mungkin karena ketiadaan pangan dirumah tangga, atau mungkin karena kelalaian orang tua dalam pengasuhan bayi dan anak balita, sehingga asupan gizi anak tidak terawasi dengan baik, sehingga timbul masalah gizi buruk. $\mathrm{Hal}$ tersebut sesuai dengan hasil wawancara mendalam dengan Kader Posyandu bahwa balita gizi buruk yang mendapatkan PMT berasal dari keluarga mampu tetapi orang balita kurang memperhatikan asupan makan anaknya karena sang ayah sudah pergi kerja pagi- pagi dan mulai kurangnya perhatian sang ibu dikarenakan sibuk mengurus anaknya yang ketiga yang baru saja lahir."

\section{Fokus III Gambaran Tentang Rujukan Balita KEP ke Puskesmas}

Informan 1 Kader Posyandu (KP) :

"Ketika kami mengetahui bahwa ada balita yang KEP di wilayah kami, kami dan bidan desa di Poskeskel langsung mendatangi rumah balita tersebut. Pada saat kami mendatangi rumah tersebut, kami langsung mengukur $B B$ dan TB anak tersebut. Ketika mengetahui bahwa benar $B B$ anak tersebut di bawah normal, maka kami langsung merujuk anak tersebut untuk dibawa ke Puskesmas Raja Basa Indah untuk mendapatkan penanganan yang lebih lanjut dan untuk mengetahui penyebab pasti dari masalah anak tersebut melalui bidan desa lalu bidan desa yang membuatkan surat rujukan ke Puskesmas Raja Basa Indah. Bukan hanya itu, apabila ada anak yang berat badannya turun/ tidak naik 3 kali berturut-turut pada saat dilakukan posyandu atau didapatkan balita dengan BB yang tidak sesuai dengan umurnya dan terdapat tanda-tanda gizi buruk langsung dikonsultasikan kepada bidan atau dokter yang hadir pada saat posyandu, dan apabila ada anak yang mengalami gizi buruk maka balita tersebut langsung dirujuk ke Puskesmas untuk dilakukan pemeriksaan lebih lanjut sehingga status gizi balita tersebut dapat dipastikan. Namun sebelumnya balita tersebut diperiksa kembali oleh dokter untuk mengetahui adanya penyakit penyerta, bila penyakit yang menyertai tidak dapat diatasi di Puskesmas maka akan dirujuk ke rumah sakit. Kendala yang dihadapi adalah meyakinkan orangtua balita untuk membawa anaknya ke Puskesmas untuk mendapatkan penanganan yang lebih lanjut dikarenakan orangtua meyakini bahwa anak mereka kurus dikarenakan perawakan sang ibu yang juga kurus bukan karena terkena penyakit lain ataupun kurang gizi."

\section{PEMBAHASAN \\ Gambaran Tentang Perencanaan Dalam Manajemen Penanganan Balita KEP}

Perencanaan merupakan salah satu fungsi manajemen kesehatan yang harus dilakukan oleh puskesmas dalam upaya mencapai tujuan dari suatu program. Perencanaan pada program tersebut, dan perencanaan pada puskesmas harus disesuaikan dengan analisa situasi yang ada pada program tersebut dan perencanaan terhadap suatu kegiatan harus dilakukan setiap tahunnya, dengan menyusun waktu, dana, jadwal kegiatan, penanggung jawab tiap kegiatan, sasaran, dan target kedepan yang mesti diikuti pada kegiatan nantinya. Trisnantoro, 1996 menyatakan perencanaan merupakan salah satu fungsi manajemen kesehatan yang harus dilaksanakan oleh puskesmas dalam upaya mencapai tujuan dari suatu program. Keberhasilan suatu perencanaan terutama tergantung pada perilaku individu, motivasi, dan kecakapan. Suatu definisi sederhana tentang perencanaan yang diorganisasi adalah penggunaan pendekatan sistematis yang memungkinkan beraneka ragam individu untuk sepakat melaksanakan kegiatankegiatan rumit dengan cara memberi kepuasan timbal- balik. Perencanaan tenaga dimaksudkan untuk sekedar menunjukk penanggung jawab atau pemegang program. Petugas gizi puskesmas merupakan penanggung 
jawab program penatalaksanaan balita gizi buruk akan tetapi dibantu oleh tenaga kesehatan yang lain dan para kader posyandu. Perencanaan sudah sesuai dengan kriteria anak gizi buruk yang ada pada buku petunjuk dan penemuan kasus di posyandu kemudian dirujuk ke puskesmas.

Ketika menemukan balita

kurang gizi penting untuk mendapatkan konseling gizi untuk mencari penyebab masalah sebelum memberi nasihat kepada ibu. Apabila ada masalah dalam pertumbuhan balita dan kecenderungan yang mengarah pada suatu masalah, maka perlu mewawancarai ibu untuk mengidentifikasi penyebab masalah yang ada. Selama konseling, sangat penting untuk menyepakati tindakan untuk meningkatkan pertumbuhan anak yang dapat dilaksanakan oleh ibu atau pengasuh. Berdasarkan hasil penelitian yang didapat dari informan kegiatan konseling dilakukan secara tatap muka kepada orang tua anak. Istilah konseling berasal dari bahasa Inggris "to counsel" yang secara etimologis berarti "to give advice" atau memberi saran dan nasehat. Konseling merupakan salah satu teknik dalam pelayanan bimbingan dimana proses pemberian bantuan itu berlangsung melalui wawancara dalam serangkaian pertemuan langsung dan tatap muka antara konselor dengan klien dengan tujuan agar klien mampu untuk memperoleh pemahaman yang lebih baik terhadap dirinya, mampu memecahkan masalah yang dihadapinya dan mampu mengarahkan dirinya untuk mengembangkan potensi yang dimiliki ke arah perkembangan yang optimal, sehingga ia dapat mencapai kebahagiaan pribadi dan kemanfaatan sosial. Konseling juga termasuk salah satu cara untuk membantu seseorang dan merupakan suatu teknik untuk sebuah intervensi, dan untuk pengubahan tingkah laku. (DepkesRI, 2008a) Kegiatan konseling diberikan baik dari kader posyandu, puskesmas maupun dari dinas kesehatan kota. Pemberian konseling perlu dilakukan untuk menyampaikan informasi kepada ibu tentang hasil penilaian pertumbuhan anak dan untuk memberikan anjuran pemberian makanan sesuai umur dan kondisi anak dan cara menyiapkan makanan, melaksanakan anjuran makan dan memilih atau mengganti makanan. Menurut Depkes RI (2008b), dengan adanya teknik membangun kepercayaan dan memberikan dukungan maka akan terjalin komunikasi antara petugas gizi ataupun kader dengan ibu balita. Dengan adanya penyampaian informasi oleh petugas gizi dan kader diharapkan dapat merubah perilaku ibu balita KEP dalam pola pengasuhan sehingga keberhasilan konseling tersebut dapat tercapai, namun dengan pengetahuan yang cukup tidak merubah perilaku seseorang tanpa adanya motivasi. Masalah gizi adalah masalah kesehatan masyarakat yang penanggulangannya tidak dapat dilaksanakan dengan pendekatan medis dan pelayanan kesehatan saja, sehingga memerlukan dukungan lintas sektor. (M. Sururi, 2006) Mengingat penyebabnya sangat kompleks, pengelolaan gizi buruk memerlukan kerjasama yang komprehensif dari semua pihak. Bukan hanya dari dokter maupun tenaga medis, namun juga pihak orangtua, keluarga, pemuka masyarakat maupun agama dan pemerintah. Perencanaan sudah sesuai dengan kriteria anak gizi buruk yang ada pada buku petunjuk dan penemuan kasus di posyandu kemudian dirujuk ke puskesmas. Alur pelayanan untuk balita gizi buruk dilakukan pemeriksaan klinis oleh dokter dan diberikan konseling atau nasihat oleh ibu kordinator gizi. Penanggung jawab untuk buku laporan adalah kordinator gizi.

\section{Gambaran Tentang Pelaksanaan Dalam Manajemen Penanganan Balita KEP}

Pelaksanaan balita gizi buruk secara efektif dan efisien diperlukan adanya junik (petunjuk teknis) pelaksanaan program agar alur pengelolaan dan pendistribusian 
berjalan teratur sehingga dapat sampai ke sasaran dalam keadaan baik. Pelaksanaan merupakan tujuan utama dari semua kegiatan program yang telah direncanakan untuk mencapai tujuan program. Pelaksanaan program penatalaksanaan balita gizi buruk dilakukan petugas gizi dan kader posyandu yang bertugas di wilayah kerja Puskesmas Raja Basa Indah Bandar Lampung di bawah pengawasan kepala Puskesmas.

Buku pedoman penanganan gizi buruk merupakan acuan bagi petugas gizi baik di tingkat kota maupun puskesmas serta pihak terkait lainnya. Selain itu, fungsi buku pedoman program agar apa yang telah direncanakan dapat berjalan sesuai dengan juknis yang ada sehingga dapat diukur keberhasilan suatu program. Program penatalaksanaan balita gizi buruk merupakan salah satu upaya pemerintah untuk mencapai derajat kesehatan setinggi-tingginya, mencegah dan menanggulangi balita gizi buruk. Sasaran program penatalaksanan balita gizi buruk itu adalah balita gizi buruk. Pelaksanaan dari program penatalaksanaan balita gizi buruk menurut buku pedoman dilihat dari penyediaan sarana pendukung dan yang menjadi sarana pendukung yaitu PMT. Program penatalaksanaan balita gizi buruk dilihat dari kriteria anak gizi buruk dan dapat disimpulkan bahwa kriteria anak gizi buruk dapat dilihat dari body image pada gizi buruk tanpa komplikasi dan demam sangat tinggi pada gizi buruk dengan komplikasi.

Ketika mendapatkan balita gizi kurang, petugas gizi langsug memberikan PMT kepada kader posyandu dan bidan desa untuk diberikan kepada balita KEP. Dan menurut keterangan dari informan dapat disimpulkan bahwasanya kader posyandu dan petugas gizi dari puskesmas berperan aktif dalam menangani kasus KEP, dimulai dari pemberian PMT oleh kader posyandu kepada para orang tua yang anaknya menderita KEP. Hal ini sudah sesuai dengan teori yang menyatakan bahwa untuk mengatasi kekurangan gizi yang terjadi pada kelompok usia balita perlu diselenggarakan Pemberian Makanan Tambahan (PMT) Pemulihan. PMT Pemulihan bagi anak usia 6-59 bulan dimaksudkan sebagai tambahan, bukan sebagai pengganti makanan utama sehari-hari. PMT pemulihan diberikan dalam bentuk makanan atau bahan makanan lokal. Jika bahan makanan lokal terbatas, dapat digunakan makanan pabrikan yang tersedia di wilayah setempat dengan memperhatikan kemasan, label, dan masa kadaluarsa untuk keamanan pangan. Makanan tambahan diberikan sekali sehari selama 90 hari berturut-turut. Makanan tambahan pemulihan berbasis bahan makanan atau makanan lokal ada dua jenis yaitu berupa MP- ASI (untuk bayi dan anak berusia 6-23 bulan) dan makanan tambahan untuk pemulihan anak balita usia 24-59 bulan berupa makanan keluarga. (Kemenkes, 2012) PMT Pemulihan dimaksud berbasis bahan makanan lokal dengan menu khas daerah yang disesuaikan dengan kondisi setempat.

Berdasarkan penelitian diatas tentang program posyandu yang dilakukan oleh kader posyandu, menurut informan anak yang menderita gizi buruk diberikan Pemberian Makanan Tambahan (PMT) berupa roti dari puskesmas. Biasanya dibagi sekitar 20 kotak khusus untuk anak yang gizi kurang atau gizi buruk, yang dalam waktu satu minggu harus habis dua kotak selama tiga bulan. Program pelayanan posyandu sudah berjalan efektif. Kegiatan konseling tentang gizi buruk sering dilakukan saat diadakan posyandu.

Menurut KemenkesRI, 2011 peran puskesmas terhadap pencegahan dan penanganan terjadinya kasus gizi buruk atau KEP yaitu PMT yang setiap bulan dibagikan kepada masyarakat dan anak yang mengalami gizi buruk dibawa ke Pusat 
Pemulihan Gizi (PPG) / Therapeutic Feeding Centre (TFC). PPG merupakan suatu tempat pelayanan gizi kepada masyarakat yang ada di desa dan dapat dikembangkan dari posyandu. Pelayanan gizi di PPG difokuskan pada pemberian makanan tambahan pemulihan bagi balita KEP. Penanganan PPG dilakukan oleh kelompok orang tua balita (5-9 balita) yang dibantu oleh kader untuk menyelenggarakan PMT.

Pemulihan anak balita. Layanan yang dapat diberikan adalah:

1. Balita KEP berat/gizi buruk yang tidak menderita penyakit penyerta lain dapat dilayani di PPG

2. Kader memberikan penyuluhan gizi/kesehatan serta melakukan demonstrasi cara menyiapkan makanan untuk anak KEP berat/gizi buruk.

3. Kader menimbang berat badan anak setiap 2minggu sekali untuk memantau perubahan berat badan dan mencatat keadaan kesehatannya.

a. Bila anak berat badannya tidak naik atau tetap maka berikan penyuluhan gizi seimbang untuk dilaksanakan di rumah.

b. Bila anak sakit dianjurkan untuk memeriksakan anaknya ke puskesmas.

4. Makanan tambahan diberikan dalam bentuk makanan jadi dan diberikan setiap hari.

a. Bila makanan tidak memungkinkan untuk dimakan bersama, makanan tersebut diberikan satu hari dalam bentuk matang selebihnya diberikan dalam bentuk bahan makanan mentah.

b. Apabila berat badan anak berada di pita warna kuning pada KMS teruskan pemberian PMT pemulihan sampai 90 hari.

c. Apabila setelah 90 hari, berat badan anak belum berada di pita warna hijau pada KMS kader merujuk anak ke puskesmas

b. untuk mencari kemungkinan penyebab lain.
5. Apabila berat badan anak berada pada pita warna hijau pada KMS, kader menganjurkan pada ibu untuk mengikuti pelayanan di posyandu setiap bulan dan tetap melaksanakan anjuran gizi dan kesehatan yang telah diberikan.

6. Ibu memperoleh penyuluhan gizi/ kesehatan serta demonstrasi cara menyiapkan makanan untuk anak KEP.

7. Kader menganjurkan pada ibu untuk tetap melaksanakan nasehat yang diberikan tentang gizi dan kesehatan.

8. Kader melakukan kunjungan rumah untuk memantau perkembangan kesehatan dan gizi anak (Surveilans gizi)

Surveilans gizi dilakukan setiap minggu oleh kader kesehatan dengan mengunjungi rumah balita gizi buruk serta mengadakan pengamatan secara terus-menerus terhadap tumbuh kembang balita gizi buruk dan kurang yang merupakan kelompok binaannya masing- masing. Surveilans adalah proses pengamatan berbagai masalah yang berkaitan dengan suatu program secara terus menerus melalui pengumpulan, pengolahan, analisis dan interpretasi secara sistematis serta penyebaran informasi kepada unit terkait dalam rangka pengambilan tindakan. Surveilans memiliki peran penting dalam penyediaan informasi kinerja dan dampak dari program yang dilaksanakan. (Depkes, 2008). Menurut Kementrian Kesehatan RI (2012) bahwa surveilans gizi adalah suatu proses pengumpulan, pengolahan dan deseminasi informasi hasil pengolahan data secara terus menerus dan teratur tentang indikator yang terkait dengan kinerja pembinaan gizi masyarakat. Hal ini sudah sesuai dengan teori menurut Kemenkes RI (2011) mengenai alur 
surveilans. Di beberapa negara miskin, biasanya anak-anak yang menderita malnutrisi gizi buruk akut tidak pernah dibawa ke tenaga atau fasilitas kesehatan. Pada kasus seperti ini, perlu adanya pendekatan kepada masyarakat yang berpengaruh (tokoh masyarakat, dan lain-lain) agar dapat melaksanakan perawatan pada anak yang sakit. Bukti telah menunjukkan bahwa sekitar $80 \%$ anak dengan malnutrisi buruk akut yang telah teridentifikasi merupakan temuan kasus yang aktif. (WHO,2007) Penjaringan secara pasif dilakukan di Puskesmas apabila penderita datang ke Puskesmas untuk memeriksakan penyakitnya dan saat itu diketahui balita tersebut menderita gizi buruk, juga didapatkan laporan dari kader bahwa ada gizi buruk diwilayah kerja Puskesmas.

Kegiatan penjaringan yang dilakukan oleh Puskesmas Raja Basa Indah tersebut sesuai dengan langkah-langkah penemuan, yaitu: (M Sururi, 2006)

1. Mendatangi posyandu atau rumah balita yang diduga menderita gizi buruk

2. Menyiapkan atau menggantungkan dacin pada tempat yang aman

3. Menanyakan tanggal/kelahiran anak

4. Menimbang balita

5. Mencatat hasil penimbangan

6. Menilai status gizi balita dengan indeks BB/U standart WHO-NCHS

7. Mencatat nama balita menderita gizi buruk

8. Membuat laporan KLB ke DKK

Pelacakan pada balita gizi buruk dilakukan untuk mengetahui faktorfaktor yang berkaitan dengan kejadian gizi buruk dengan melalui wawancara dan pengamatan. Pelacakan dilaksanakan setelah terjadi penjaringan atau didapatkan kasus balita gizi buruk dengan mendatangi rumah balita gizi buruk tersebut. Kegiatan yang dilakukan dalam pelacakan balita gizi buruk di wilayah Puskesmas Raja Basa Indah diantaranya adalah melakukan tanya jawab langsung kepada orang tua balita gizi buruk, melakukan rujukan ke Puskesmas atau ke rumah sakit bila ada penyakit yang menyertai.

\section{Gambaran Tentang Rujukan Balita KEP ke Puskesmas}

Rujukan dalam pelayanan merupakan kegiatan pengiriman orang sakit dari unit kesehatan yang kurang lengkap ke unit yang lebih lengkap. Simba (2008) mengatakan bahwa prinsip dalam menentukan tempat rujukan adalah fasilitas pelayanan yang mempunyai kewenangan dan terdekat termasuk fasilitas pelayanan swasta dengan tidak mengabaikan kesediaan dan kemampuan penderita. Rujukan dilakukan apabila perujuk tidak dapat memberikan pelayanan kesehatan sesuai dengan kebutuhan pasien karena keterbatasan fasilitas, peralatan atau ketenagaan yang sifatnya sementara atau menetap.

(2012) mengatakan bahwa keuntungan mekanisme sistem rujukan adalah pelayanan yang diberikan bisa sedekat mungkin ke tempat pasien, berarti bahwa pertolongan dapat diberikan lebih cepat, murah dan secara psikologis memberi rasa aman pada pasien dan keluarga. Sesuai dengan teori diatas, dapat disimpulkan bahwa apa yang telah informan lakukan sudah sesuai dengan teori rujukan. Kader selalu melakukan rujukan ke Puskesmas apabila menemukan ada anak yang berat badannya turun/ tidak naik 3 kali berturut-turut pada saat dilakukan posyandu atau didapatkan balita dengan BB yang tidak sesuai dengan umurnya dan terdapat tanda-tanda gizi buruk langsung dikonsultasikan kepada bidan atau dokter yang hadir pada saat posyandu, dan apabila ada anak yang mengalami gizi buruk maka balita tersebut langsung dirujuk ke Puskesmas untuk dilakukan pemeriksaan lebih lanjut sehingga status gizi balita tersebut dapat dipastikan dan apabila setelah 90 hari, berat badan anak belum berada di pita warna hijau pada KMS kader merujuk 
anak ke puskesmas untuk mencari kemungkinan penyebab lain.

\section{Kesimpulan}

Berdasarkan hasil penelitian dan pembahasan tentang analisis peran Kader Posyandu dalam Manajemen Penanganan Balita KEP di Puskesmas Raja Basa Indah Bandar Lampung yang didapat dari informan kunci, yaitu Petugas Gizi Puskesmas Raja Basa Indah, pelaksana program (Kader Posyandu Dahlia), dan informan lainnya yaitu Ketua RT wilayah rumah pasien Balita KEP didapat :

1. Dalam melakukan proses pelaporan dan perencanaan dalam manajemen penanganan balita KEP yang dilakukan oleh Kader Posyandusudah berjalan cukup baik dan sesuai dengan yang ada di juknis penanganan balita gizi buruk.

2. Dalam melakukan proses pelaksanaan dalam manajemen penanganan balita KEP yang dilakukan oleh Kader Posyandu sudah berjalan cukup baik dan sesuai dengan yang ada di juknis penanganan balita gizi buruk.

3. Peranan kader posyandu dalam merujuk balita KEP tersebut untuk dibawa ke Puskesmas sudah baik dan sesuai dengan juknis yang berlaku ketika menemukan anak balita yang kurang gizi/gizi buruk.

\section{DAFTAR PUSTAKA}

Depkes RI. (2008). Petunjuk Teknis Bantuan Sosial Program Perbaikan Gizi Masyarakat. Jakarta: Departemen Kesehatan Republik Indonesia Bina Kesehatan Masyarakat Direktorat Bina Gizi Masyarakat.

Dinkes. (2016). Profil Data Kesehatan Provinsi Lampung tahun 2015. Dinas Kesehatan Provinsi
Lampung.

Fitri W. (2005). Gambaran Peran Kader Posyandu di Posyandu Desa Sraturejo Kecamatan Baureno Kabupaten Bojonegoro tahun 2005. Bojonegoro; Akes Rajekwesi

Kemenkes RI. (2012). Buku Posyandu. Diakses pada tanggal $15 \quad$ November 2016 dihttp://promkes.depkes.go.id

Riset Kesehatan Dasar (RISKESDAS) 2013. Jakarta: Kemenkes Kurnia

Purwito, N \& Pusponegoro. (2012). Efektivitas Sistem Rujukan Maternal dan Neonatal di Jakarta Timur. Journal Indonesia Medicine Association, Vol 62, No 11

Simba.(2008). Referral Pattern of Patients Received at the National Referral Hospital. Journal of Public Health, Vol 5, No 1

Supariasa, I. D. N. (2013). dkk: Penilaian Status gizi (Edisi Revisi). Jakarta: Buku Kedokteran EGC.

Sururi, M. (2006). Penanggulangan gizi buruk. Akses di http://www. dinkes purworejo. go. id/index2. php.

Trisnantoro, L. (1996). Prinsip-Prinsip Manajemen Pelayanan Kesehatan (Doctoral dissertation, Tesis. Yogyakarta: Universitas Gadjah Mada).

Secretariat, W. H. O., Andersson, M., De Benoist, B., Delange, F., \& Zupan, J. (2007). Prevention and control of iodine deficiency in pregnant and lactating women and in children less than 2-years-old: conclusions and recommendations of the Technical Consultation. Public health nutrition, 10(12A), 1606-1611. 